\title{
In vitro antioxidant and anti-inflammatory activities of the chloroform extract of Combretum punctatum var squamosum
}

\author{
K. Thanzami*, B.B. Kakoti, C. Lalremruati \\ Department of Pharmacy, Regional Institute of Pharmacy and Nursing Sciences, Aizawl 796017, India
}

\begin{abstract}
The objective of this study was to investigate the antioxidant and antiinflammatory activities of the chloroform extract of Combretum punctatum var squamosum by in vitro models. Antioxidant activity was determined by 2, 2diphenyl-1-picrylhydrazyl (DPPH) radical scavenging activity, reducing power and lipid peroxidation assays. The phenolic and flavonoid contents of the extract were also assessed. The extract at different concentrations showed significant percent inhibition of DPPH and lipid peroxidation and high reducing power when compared with the standard. The extract also showed a significantly high content of phenolics and flavonoids. Anti-inflammatory activity was studied by inhibition of albumin denaturation and human red blood cell (HRBC) membrane stabilization methods. The extract at different concentrations showed significant percent inhibition of albumin denaturation and percent inhibition of haemolysis when compared with the standard. Thus, the result indicates that the chloroform extract exhibited significant potential on anti-inflammatory and antioxidant activities.
\end{abstract}

Keywords: Anti-inflammatory, antioxidant, Combretum punctatum var squamosum, chloroform, inhibition.

\section{Introduction}

Plants have played an important role in the treatment of human diseases since ancient times till today, particularly in the developing world. ${ }^{1}$ They have always acted as important sources of therapeutically active compounds. ${ }^{2}$ The utilisation of plants for curing illnesses was based only on experiences and no sufficient information is available on the usage of medicinal plants for the treatment of diseases. In time, discovery of the reasons for the usage of specific medicinal plants for treatment of certain diseases was achieved and thus, the medicinal plants' usages are gradually based on scientific data and facts. ${ }^{3}$ There is a great challenge on research of the traditional medicinal plants for their constituents and therapeutic activities.
Combretum punctatum var. squamosum (Roxb. Ex. G. Don), belonging to the family Combretaceae, is a deciduous climber found mainly in South-east Asian countries like India, Myanmar, Bangladesh, Bhutan, Nepal, Philippines, Thailand, Vietnam and China. It is locally known as 'leihruisen' in Mizo language. ${ }^{4}$ Traditionally, the juice of the fresh leaves is applied to wounds and cuts to stop bleeding; the broths of boiled leaves are taken as medicine for diarrhoea and cholera. ${ }^{5}$ However, no proper investigations on activity of the plant have been done. The present study aimed for in vitro evaluation of antiinflammatory and antioxidant activity of the plant. 


\section{Materials and Methods}

\section{Materials}

Soxhlet apparatus, petroleum ether, chloroform, simple distillation unit, 2, 2-diphenyl-1-picrylhydrazyl (DPPH), butylated hydoxytoluene (BHT), ultravioletvisible (UV-Vis) spectrophotometer, methanol, incubator, ascorbic acid, potassium ferricyanide, trichloroacetic acid, centrifuge, gallic acid, FolinCiocalteu reagent, sodium carbonate, quercetin, sodium nitrite $\left(\mathrm{NaNO}_{2}\right)$, aluminium chloride $\left(\mathrm{AlCl}_{3}\right)$, sodium hydroxide $(\mathrm{NaOH})$, egg yolk, $\mathrm{FeSO}_{4}$, acetic acid, sodium dodecyl sulphate, butanol, diclofenac sodium, hydrochloric acid $(\mathrm{HCl})$, bovine albumin, human red blood cell (HRBC), Alsevers solution, normal saline, hyposaline, test tubes, etc.

\section{Collection of plant material}

The leaves of Combretum punctatum var. squamosum were collected from Khanpui village, Aizawl District, Mizoram, NE India during April, 2018. The plant was identified by Botanical Survey of India, Kolkata. A voucher specimen (IBTH-1) is being preserved in the Department of Pharmacy, RIPANS, for further reference. The leaves were cleaned and dried under shade to remove moisture with occasional shifting and then powdered with a mechanical grinder. It was then subjected to successive extraction of phytoconstituents using Soxhlet apparatus.

\section{Extraction of phytoconstituents}

The dried powdered leaves of the plant were defatted with petroleum ether and the defatted powdered material thus obtained was further extracted with chloroform in a Soxhlet apparatus. The extraction was carried out exhaustively and the solvents were recovered by simple distillation. The extract was concentrated and dried to yield free flowing powder.

\section{DPPH radical-scavenging activity}

The antioxidant activity of extract and the standard were estimated according to the method described by Blois (1958) with minor changes. ${ }^{6}$ Butylated hydroxytoluene (BHT) was used as reference standard. A mixture consisting of $0.5 \mathrm{ml}$ of DPPH solution in methanol $(0.1 \mathrm{mM})$ and $3 \mathrm{ml}$ of the methanol extract and $3 \mathrm{ml}$ of standard prepared in various concentrations $(0.1,0.5,1,2,3,4,5 \mu \mathrm{g} / \mathrm{ml})$, respectively was prepared. All the mixtures were incubated for 30 minutes at $37^{\circ} \mathrm{C}$. Absorbance was measured at $517 \mathrm{~nm}$ using ultraviolet-visible (UVVis) spectrophotometer. Control reading was also taken. The scavenging effect of DPPH free radical was calculated using the following equation:

$\%$ DPPH radical scavenging

$=\frac{\text { (Abs of Control }- \text { Abs of extract })}{\text { Abs of Control }} \times 100$

\section{Determination of reducing power}

The reducing power of extract was determined by the method of Oyaizu. ${ }^{7}$ Ascorbic acid was used as reference standard. $1 \mathrm{ml}$ of the extract and $1 \mathrm{ml}$ of the standard with various concentrations $(10,20,40$, 60,80 , and $100 \mu \mathrm{g} / \mathrm{ml}$ ) were mixed with $2.5 \mathrm{ml}$ of phosphate buffer $(6.6 \mathrm{pH})$ and $2.5 \mathrm{ml}$ of $1 \%$ potassium ferricyanide. The mixture was then incubated at $50^{\circ} \mathrm{C}$ for 30 minutes. The reaction was stopped by adding $2.5 \mathrm{ml}$ of $10 \%$ trichloroacetic acid and the mixture was centrifuged at $3000 \mathrm{rpm}$ for 10 minutes. $2.5 \mathrm{ml}$ of the supernatant was mixed with $2.5 \mathrm{ml}$ of distilled water, and $0.5 \mathrm{ml}$ of $0.1 \%$ ferric chloride solution and the absorbance was taken at $700 \mathrm{~nm}$ using UV-Vis spectrophotometer. The higher absorbance of the reaction mixture indicated that the reducing power is increased.

\section{Determination of total phenolic content}

The total phenolic content of extract was determined using the method of Mc Donald et al., ${ }^{8}$ with slight modifications. A standard calibration curve was prepared by using gallic acid. $1 \mathrm{ml}$ of methanolic solution of gallic acid $(10,20,40,60,80$, and $100 \mu \mathrm{g} / \mathrm{ml}$ ) was mixed with $5 \mathrm{ml}$ Folin-Ciocalteu reagent (diluted tenfold). After 3 minutes, $4 \mathrm{ml}$ of sodium carbonate solution $(0.7 \mathrm{M})$ was added, and the mixture was allowed to stand for $1 \mathrm{hr}$ at room temperature. Absorbance was measured at $765 \mathrm{~nm}$ using UV-Vis spectrophotometer. $1 \mathrm{ml}$ of the extract $(50 \mathrm{mg} / \mathrm{ml}$ ) was also mixed with the reagents above and after $1 \mathrm{hr}$ the absorbance was measured to determine total plant phenolic content. From the calibration curve, the amount of phenolic compounds was determined and expressed as milligrams of gallic acid equivalent (GAE)/g of the dried extract.

\section{Determination of total flavonoids content}

The total flavonoid content of the extract was determined by the aluminum chloride method. ${ }^{9} \mathrm{~A}$ standard curve was prepared with quercetin at different concentrations $(10,20,40,60,80$, and 100 $\mu \mathrm{g} / \mathrm{ml}) .1 \mathrm{ml}$ of the extract $(50 \mathrm{mg} / \mathrm{ml})$ and $1 \mathrm{ml}$ of quercetin were mixed with $2 \mathrm{ml}$ of distilled water. After 5 minutes, $3 \mathrm{ml}$ of $5 \%$ sodium nitrite $\left(\mathrm{NaNO}_{2}\right)$ and $0.3 \mathrm{ml}$ of $10 \%$ aluminium chloride $\left(\mathrm{AlCl}_{3}\right)$ were added. After 6 minutes, $2 \mathrm{ml}$ of $\mathrm{NaOH}(1 \mathrm{M})$ was added, and the volume was made up to $10 \mathrm{ml}$ with distilled water. After $1 \mathrm{hr}$, absorbance reading was 
taken at $510 \mathrm{~nm}$. From the calibration curve of the reference standard, the total flavonoid content was determined and expressed as milligrams of quercetin equivalent $(\mathrm{QE} / \mathrm{g})$ of dried extract.

\section{Lipid peroxidation inhibition assay}

In this assay, a modified thiobarbituric acidreactive species (TBARS) was used to measure the lipid peroxide formed, and egg yolk homogenate was used as a lipid source. ${ }^{10}$ The reaction mixture contains egg homogenate $(0.5 \mathrm{ml}$ of $10 \% \mathrm{v} / \mathrm{v}$ in distilled water) and $0.1 \mathrm{ml}$ of extract in a test tube and made up to $1 \mathrm{ml}$ with distilled water. $0.05 \mathrm{ml}$ of $\mathrm{FeSO}_{4}(0.07 \mathrm{M})$ was added to induce lipid per oxidation and incubated for $30 \mathrm{~min}$. Then $1.5 \mathrm{ml}$ of $20 \%$ acetic acid ( $\mathrm{pH}$ adjusted to 3.5 with $\mathrm{NaOH}$ ) and $1.5 \mathrm{ml}$ of $0.8 \%(\mathrm{w} / \mathrm{v})$ TBA in $1.1 \%$ sodium dodecyl sulphate and $0.05 \mathrm{ml} 20 \%$ TCA were added and the resulting mixture was vortexed and then heated at $95^{\circ} \mathrm{C}$ for $60 \mathrm{~min}$. It was cooled, and $5.0 \mathrm{ml}$ of butan- 1 -ol were added to each tube and centrifuged at 3000 rpm for $10 \mathrm{~min}$. The absorbance of the organic upper layer was measured at $532 \mathrm{~nm}^{11}$ The percentage inhibition was calculated as follows:

$$
\begin{aligned}
& \text { Percentage inhibition } \\
& =\frac{\text { Abs of Control }- \text { Abs of extract }}{\text { Abs of Control }} \times 100
\end{aligned}
$$

\section{Anti-inflammatory activity by Inhibition of albumin denaturation}

The anti-inflammatory activity of chloroform extract of Combretum punctatum var. squamosum was studied by using inhibition of albumin denaturation method according to Mizushima et al., ${ }^{12}$ and Sakat et al., ${ }^{13}$ with minor changes. Diclofenac sodium was used as the reference standard. The reaction mixture consists of test extract and standard prepared in various concentrations $(100,200,300,400$, and $500 \mu \mathrm{g} / \mathrm{ml})$ and $1 \%$ aqueous solution of bovine albumin fraction. The $\mathrm{pH}$ of the reaction mixture was adjusted using small amount of $1 \mathrm{~N} \mathrm{HCl}$. The sample extracts were incubated at $37^{\circ} \mathrm{C}$ for $20 \mathrm{~min}$ and then heated to $51^{\circ}$ $\mathrm{C}$ for $20 \mathrm{~min}$. After cooling the samples, the turbidity was measured at $660 \mathrm{~nm}$ (UV-visible spectrophotometer). The percentage inhibition of protein denaturation was calculated as follows:

Percentage inhibition

$$
=\frac{\text { Abs of Control }- \text { Abs of Test }}{\text { Abs of Control }} \times 100
$$

\section{HRBC membrane stabilization method}

The anti-inflammatory activity of chloroform extract of Combretum punctatum var. squamosum was studied by using stabilization method of human red blood cell (HRBC) membrane by hypotonicity induced membrane lysis ${ }^{14}$. Blood was collected (2 $\mathrm{mL}$ ) from healthy volunteers and was mixed with equal volume of sterilized Alsevers solution (2\% dextrose, $0.8 \%$ sodium citrate, $0.5 \%$ citric acid and $0.42 \% \mathrm{NaCl}$ in distilled water) and centrifuged at 3,000 rpm. The packed cells were washed with isosaline solution and a $10 \% \mathrm{v} / \mathrm{v}$ suspension was prepared with normal saline and kept at $4^{\circ} \mathrm{C}$ undisturbed before use. Different concentrations of chloroform extract of Combretum punctatum var. squamosum in normal saline and diclofenac sodium as standard $(50,100,200,500$ and 1,000 $\mu \mathrm{g} / 0.5 \mathrm{~mL})$ and control (distilled water instead of hypo saline to produce $100 \%$ hemolysis) were separately mixed with $1 \mathrm{~mL}$ of phosphate buffer, $2 \mathrm{~mL}$ of hyposaline and $0.5 \mathrm{~mL}$ of $10 \%$ HRBC suspension was added. All the assay mixtures were incubated at $37^{\circ} \mathrm{C}$ for 30 min and centrifuged at 3,000 rpm for $20 \mathrm{~min}$ and haemoglobin content of the supernatant solution was estimated spectrophotometrically at $560 \mathrm{~nm}$. The percentage of HRBC membrane stabilization or protection was calculated by using the following formula:

$$
\begin{aligned}
& \text { Percentage inhibition } \\
& =\frac{\text { Abs of Control }- \text { Abs of Test }}{\text { Abs of Control }} \times 100
\end{aligned}
$$

\section{Results and Discussion}

DPPH radical is one of the most widely used free radicals for testing preliminary radical scavenging activity of the plant extract. ${ }^{15} \mathrm{DPPH}$ is a stable free radical that accepts an electron or hydrogen radical to become a stable diamagnetic molecule. The hydrogen-donating ability of antioxidants is thought to be the reason of the main effect on DPPH radical scavenging. ${ }^{16} \mathrm{DPPH}$ radical scavenging activity of chloroform extract of Combretum punctatum var. squamosum and standard is shown in Table $\mathbf{1}$ and Figure 1. In this study, the extract significantly

Table 1 | Effect of chloroform extract of Combretum punctatum var. squamosum on 2, 2-diphenyl-1picrylhydrazyl (DPPH) radical scavenging activity.

\begin{tabular}{cccc}
\hline St. & $\begin{array}{c}\text { Concentratio } \\
\mathbf{n}(\boldsymbol{\mu} / \mathbf{m l})\end{array}$ & $\begin{array}{c}\text { \% Inhibition } \\
\text { of standard } \\
\text { (BHT) }\end{array}$ & $\begin{array}{c}\% \\
\text { Inhibition }\end{array}$ \\
\hline 1 & 0.1 & 46.26 & 42.8 \\
\hline 2 & 0.5 & 51.32 & 46.76 \\
\hline 3 & 1 & 58.74 & 48.92 \\
\hline 4 & 2 & 65.34 & 56.83 \\
\hline 5 & 3 & 69.61 & 58.63 \\
\hline 6 & 4 & 74.46 & 61.51 \\
\hline 7 & 5 & 79.13 & 64.38 \\
\hline
\end{tabular}




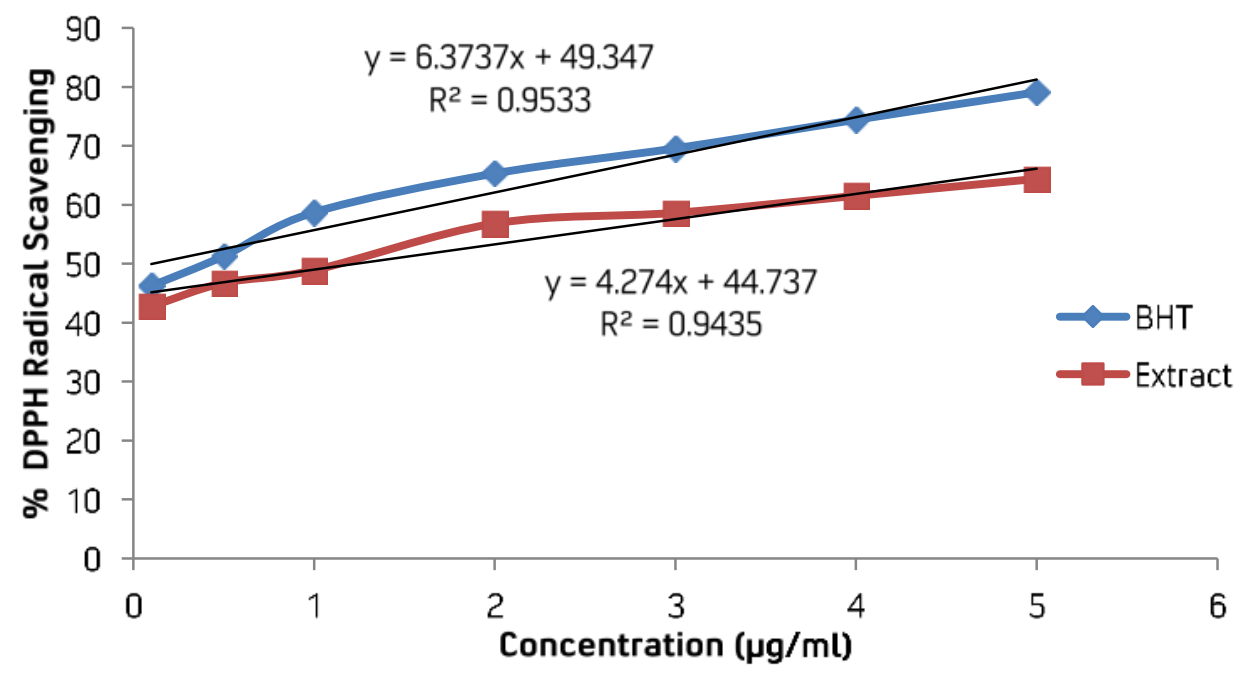

Figure 1 | Graph representing \% DPPH radical scavenging of standard (BHT) and chloroform extract of Combretum punctatum var. squamosum.

reduced the DPPH radical with increasing concentrations compared with the standard. The percentage inhibition of the DPPH radical by the chloroform extract and standard at $100 \mu \mathrm{g} / \mathrm{ml}$ was $64.38 \%$ and $79.13 \%$ respectively.

Inhibition concentration $\left(\mathrm{IC}_{50}\right)$ was determined for the interpretation of the results from DPPH method. It is defined as the concentration of the extract to scavenge $50 \%$ of the DPPH radical. The lower $I C_{50}$ value, higher is the antiradical activity. ${ }^{17}$ The percentage DPPH radical scavenging activity of the extract of the plant was plotted against standard butylated hydroxyl toluene (BHT) in a graph and shown in Figure 1. Antioxidant activity in the form of $\mathrm{IC}_{50}$ values of the plant methanol extract were calculated as $1.231 \mu \mathrm{g} / \mathrm{ml}$ compared to standard $\mathrm{BHT}$, which exhibited $0.102 \mu \mathrm{g} / \mathrm{ml}$.

The antioxidant potential of the chloroform extract of Combretum punctatum var. squamosum was also studied by determining its reducing capacity (Table 2). The ability of compounds to donate electron and to reduce the oxidized intermediates of lipid peroxidation processes are

Table 2 | Effect of chloroform extract of Combretum punctatum var. squamosum on reducing power activity.

\begin{tabular}{lccc}
$\begin{array}{l}\text { SL. } \\
\text { No }\end{array}$ & $\begin{array}{c}\text { Concentra } \\
\text { tion } \\
(\mu \mathbf{g} / \mathbf{m l})\end{array}$ & $\begin{array}{c}\text { Absorbance of } \\
\text { standard } \\
\text { (ascorbic acid) at } \\
\mathbf{7 0 0} \mathbf{~ n m}\end{array}$ & $\begin{array}{c}\text { Absorbance at } \\
\mathbf{7 0 0} \mathbf{~ n m}\end{array}$ \\
\hline 1 & 10 & 0.120 & 0.053 \\
\hline 2 & 20 & 0.497 & 0.131 \\
\hline 3 & 40 & 0.685 & 0.371 \\
\hline 4 & 60 & 0.842 & 0.462 \\
\hline 5 & 80 & 0.948 & 0.598 \\
\hline 6 & 100 & 1.031 & 0.712 \\
\hline
\end{tabular}

indications of reducing powerand they can act as primary and secondary antioxidants. The presence of an antioxidant in the extract resulted in reduction of the ferric cyanide complex $\left(\mathrm{Fe}^{3+}\right)$ to the ferrous cyanide form $\left(\mathrm{Fe}^{2+}\right)$. Concentration of ferrous ions can be determined by absorbance measurement at $700 \mathrm{~nm}$. Increased absorbance of the reaction mixture indicated increased reducing power of the extracts. ${ }^{18}$ The increase in absorbance of the extract with increasing concentration was observed, and thus proved the reducing power even though the reducing power of the plant extract were lower than the standard ascorbic acid as shown in Figure 2.

Antioxidants, such as phenolic compounds including flavonoids are distributed in the plant kingdom and may prevent oxidative damage by scavenging reactive oxygen species (ROS). ${ }^{19}$ The total phenolics and flavonoids content of the chloroform extract of Combretum punctatum var. squamosum were measured using $\mathrm{F}-\mathrm{C}$ reagent and aluminium chloride methods respectively. The chloroform extract showed the total phenol contents of 634.34 $\mathrm{mg}$ of gallic acid equivalents per gram of dry extract. Total flavonoids were found to be $386.6 \mathrm{mg}$ of quercetin equivalents per gram of dry extract respectively (Figures $\mathbf{3} \& \mathbf{4}$ ).

Lipid peroxidation is widely recognized as major toxicological event. A variety of sources including organic hydro peroxides, redox cycling compounds and iron-containing compounds caused the generation of free radicals leading to lipid peroxidation. $^{20}$ Biological membrane contains polyunsaturated lipid which are prone to oxidative reaction of free radicals, which lead to lipid peroxidation. ${ }^{21}$ In this study, the lipid peroxidation inhibitory effect of chloroform extract of Combretum punctatum var. squamosum was assessed to determinethe antioxidant activity. The inhibition of 


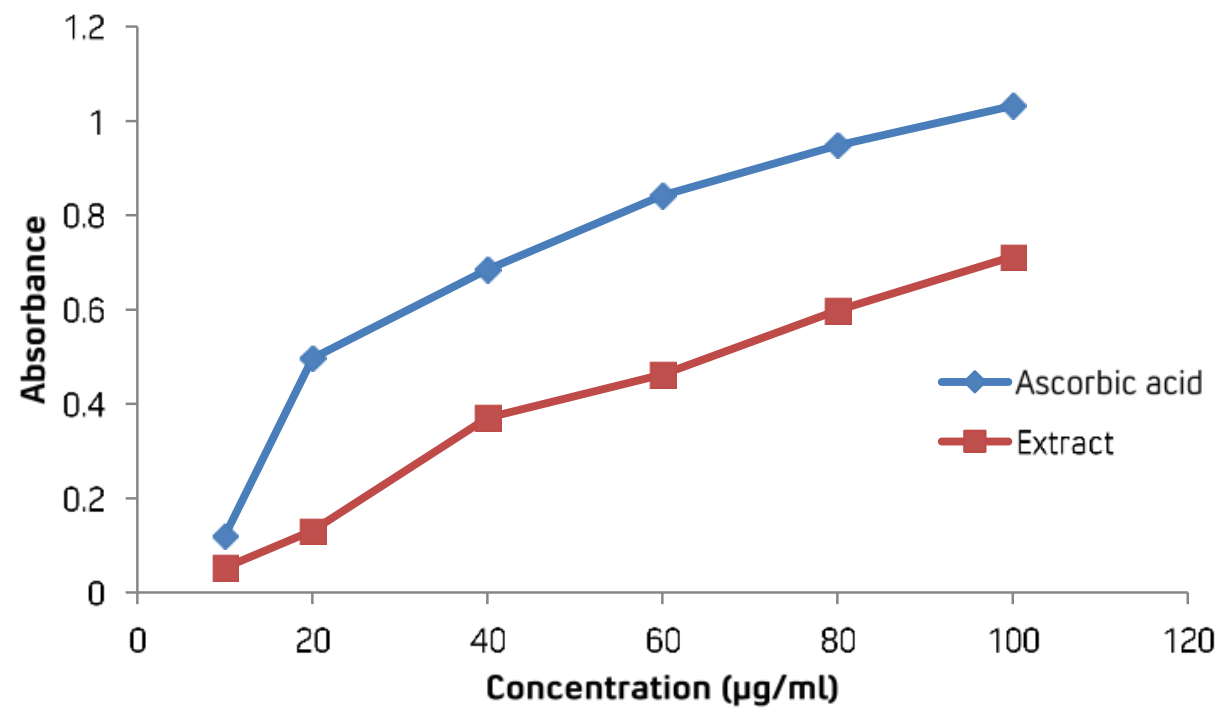

Figure 2 | Graph representing reducing power of standard (ascorbic acid) and chloroform extract of Combretum punctatum var. squamosum.

lipid peroxidation of the extract and the standard were compared and shown in Table $\mathbf{3}$ and Figure 5. Percentage inhibition of lipid peroxidation of the extract and standard at a concentration of $100 \mu \mathrm{g} / \mathrm{ml}$ were 74.86 and 86.21 respectively.

Table 3 | Effect of chloroform extract of Combretum punctatum var. squamosum on lipid peroxidation.

\begin{tabular}{cccc}
\hline $\begin{array}{c}\text { SL. } \\
\text { No }\end{array}$ & $\begin{array}{c}\text { Concentrati } \\
\text { on }(\boldsymbol{\mu g} / \mathbf{m l})\end{array}$ & $\begin{array}{c}\text { \% Inhibition } \\
\text { of standard } \\
(\boldsymbol{\alpha}-\end{array}$ & \% Inhibition \\
& & $\begin{array}{c}\text { tocopherol) } \\
\text { top }\end{array}$ & \\
\hline 1 & 10 & 59.18 & 23.78 \\
\hline 2 & 20 & 65.67 & 31.89 \\
\hline 3 & 40 & 71.62 & 45.40 \\
\hline 4 & 60 & 77.83 & 59.72 \\
\hline 5 & 80 & 81.62 & 62.97 \\
\hline 6 & 100 & 86.21 & 74.86 \\
\hline
\end{tabular}

Denaturation of proteins is a well-documented cause of inflammation. ${ }^{22}$ When bovine serum albumin (BSA) is heated it undergoes denaturation and expresses antigens associated to type III hypersensitive reaction and which are related to many inflammatory diseases. ${ }^{23}$ As part of the investigation on the anti-inflammation activity, ability of plant extract to inhibit protein denaturation of heat treated (immunogenic) bovine serum albumin (BSA) was studied. Maximum inhibition of $56.66 \%$ by the extract was observed at $500 \mu \mathrm{g} / \mathrm{ml}$. Diclofenac sodium, a standard anti-inflammatory drug showed the maximum inhibition of $90 \%$ at the concentration of $500 \mu \mathrm{g} / \mathrm{ml}$, as shown in Table 4.

The erythrocyte membrane may be considered a model of the lysosomal membrane which plays an important role in inflammation. ${ }^{24}$ During inflammation, lyses of lysosomes release their component enzymes which lead to a variety of disorders. ${ }^{25}$ Prevention of the lysis of membrane by compounds caused by the release of hydrolytic enzymes contained within the lysosomesmay relieve some symptoms of inflammation. ${ }^{26}$ It has been reported that certain saponins and flavonoids exerted profound stabilizing effect on lysosomal membrane both in vivo and in vitro. ${ }^{27}$ The antiinflammatory activity of chloroform extract of Combretum punctatum var. squamosum was investigated by HRBC membrane stabilization method. The percentage protection of erythrocyte membrane by the extract and standard was given in Table 5 and Figure 7. The extract shows maximum inhibition of $70.51 \%$ at $500 \mu \mathrm{g} / \mathrm{ml}$ compared with the standard which shows maximum inhibition of 91.66 $\%$ at $500 \mu \mathrm{g} / \mathrm{ml}$.

\section{Conclusion}

The results in the present study showed good in

Table 4 | Effect of chloroform extract of Combretum punctatum var. squamosum on albumin denaturation.

\begin{tabular}{cccc}
\hline St. No & $\begin{array}{c}\text { Concentrati } \\
\text { on }(\boldsymbol{\mu g} / \mathbf{m l})\end{array}$ & $\begin{array}{c}\text { Inhibition of } \\
\text { standard } \\
\text { (Diclofenac } \\
\text { sodium) }\end{array}$ & \% Inhibition \\
\hline 1 & 100 & 66.66 & 13.33 \\
\hline 2 & 200 & 80 & 20 \\
\hline 3 & 300 & 83 & 26.66 \\
\hline 4 & 400 & 86.66 & 43.33 \\
\hline 5 & 500 & 90 & 56.66 \\
\hline
\end{tabular}




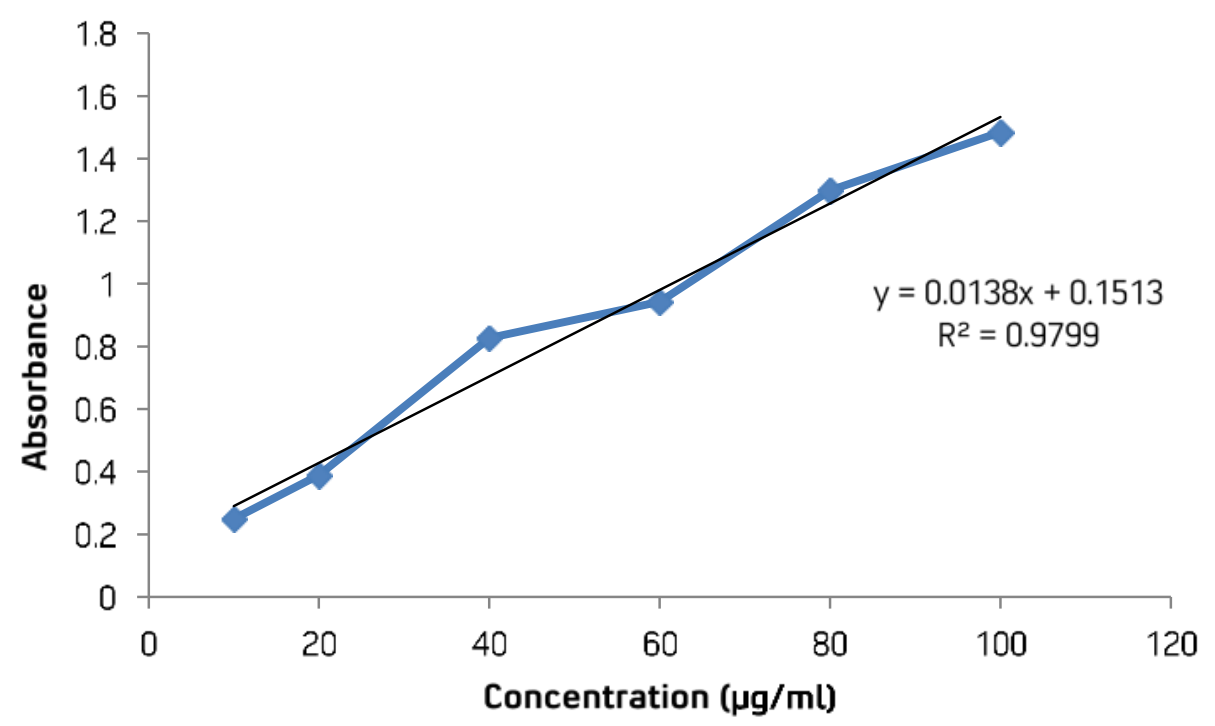

Figure 3 | Calibration curve for total phenolic content.

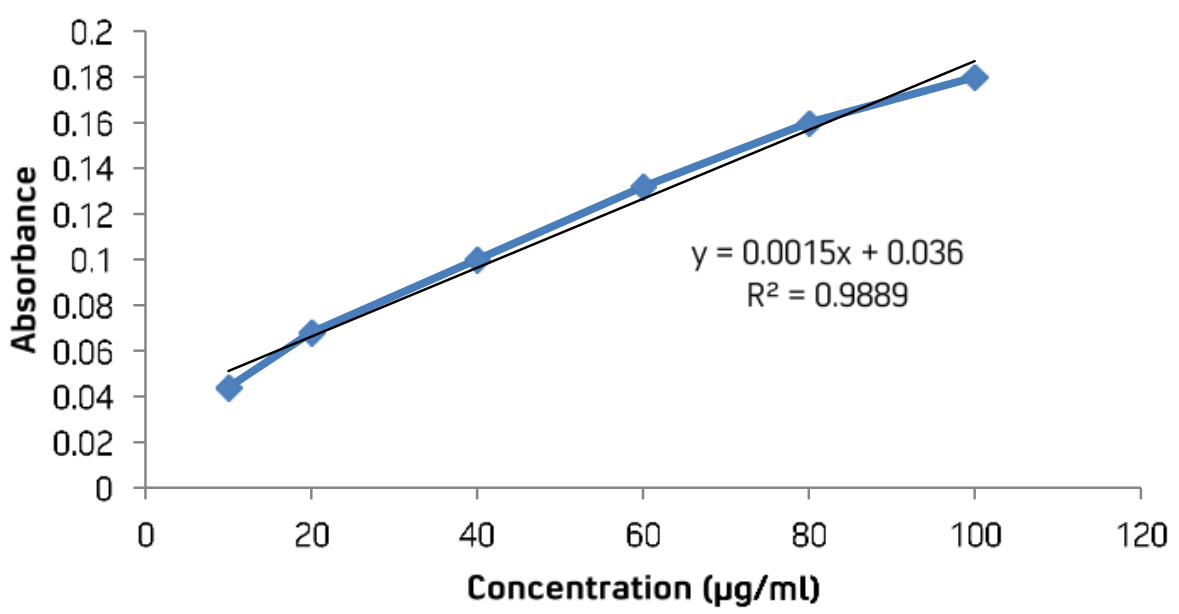

Figure 4 | Calibration curve for total flavonoid content.

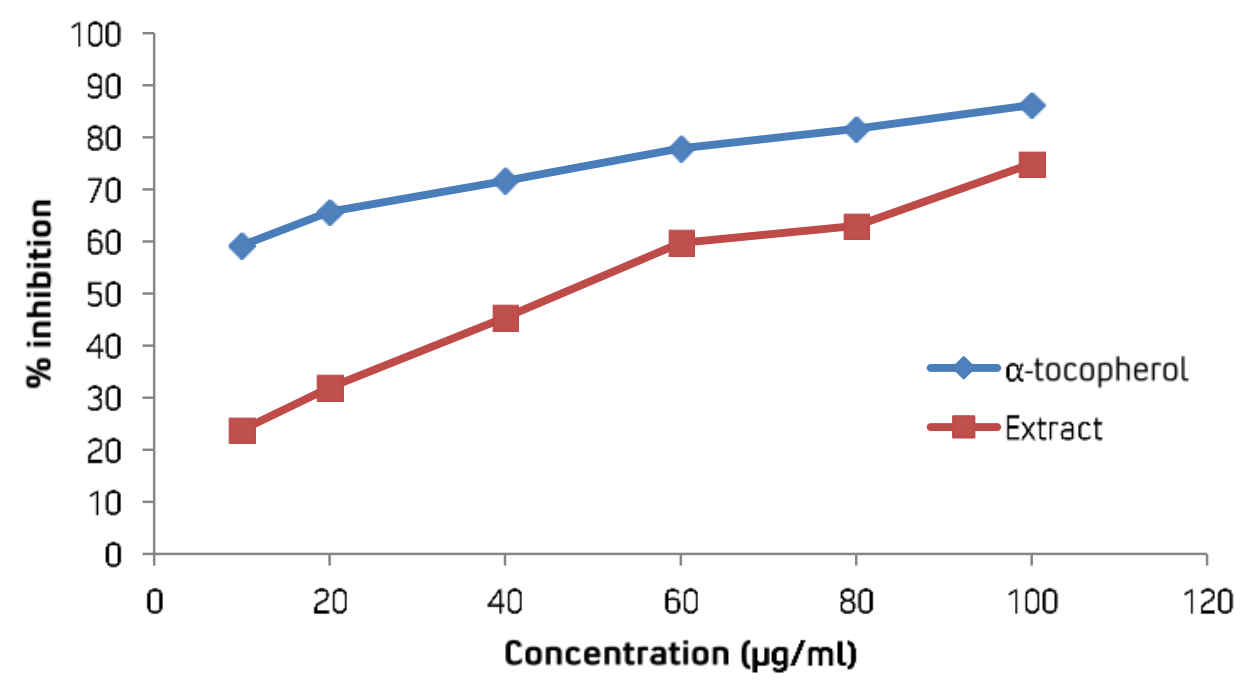

Figure 5 | Graph representing Inhibition of lipid peroxidation of standard ( $\alpha$-tocopherol) and chloroform extract of Combretum punctatum var. squamosum. 


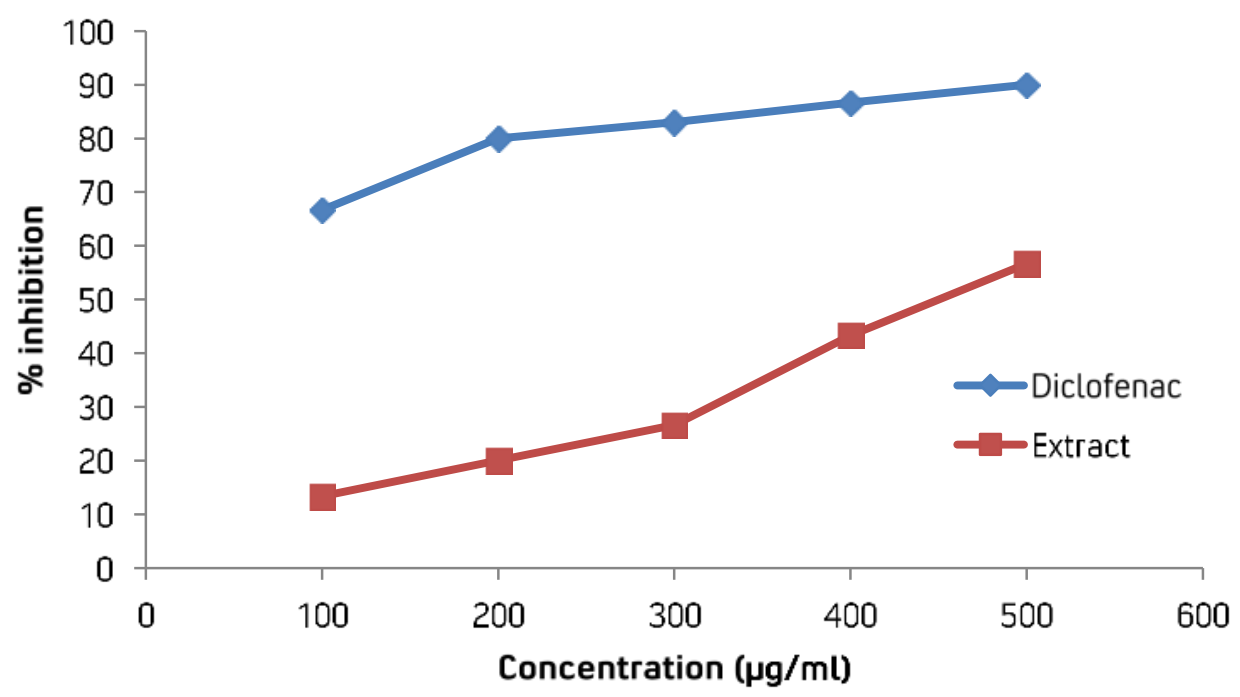

Figure 6 | Graph representing \% inhibition of albumin denaturation of standard (Diclofenac) and chloroform extract of Combretum punctatum var. squamosum.

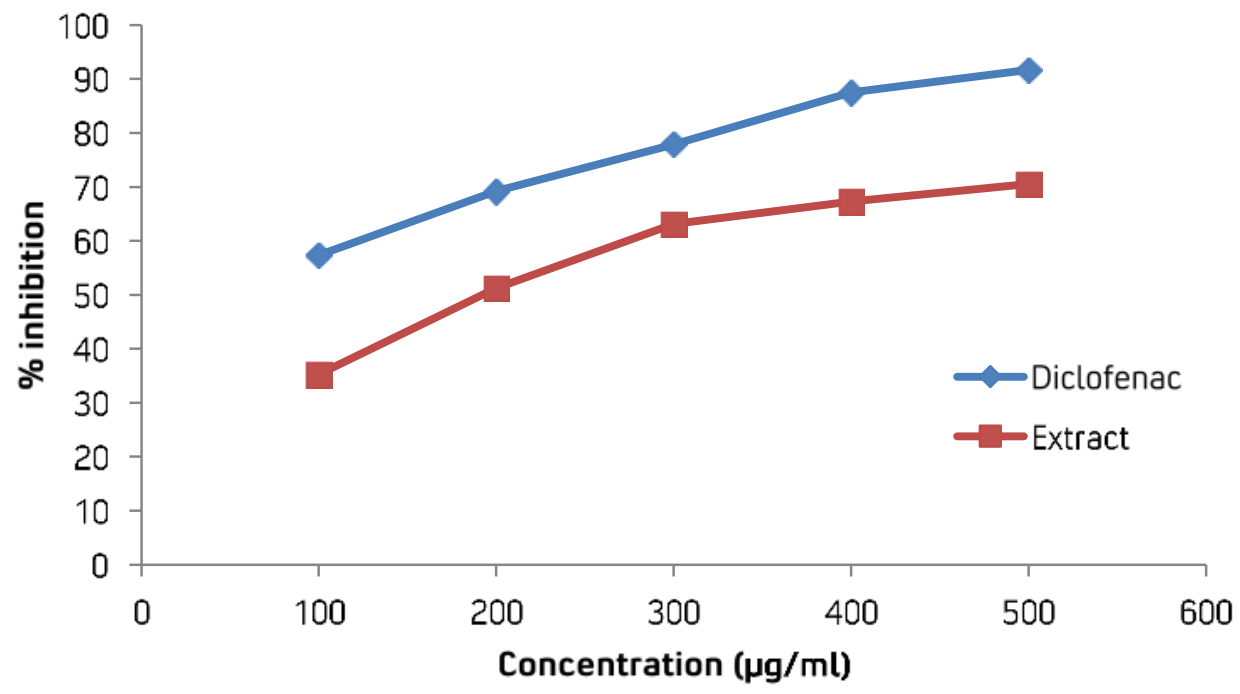

Figure 7 | Graph representing \% inhibition of HRBC membrane stabilisation of standard (Diclofenac sodium) and chloroform extract of Combretum punctatum var. squamosum.

Table 5 | Effect of chloroform extract of Combretum punctatum var. squamosum on HRBC membrane stabilisation.

\begin{tabular}{|cccc}
\hline SL. & $\begin{array}{c}\text { Concentrati } \\
\text { on }(\boldsymbol{\mu g} / \mathbf{m l})\end{array}$ & $\begin{array}{c}\text { \% Inhibition } \\
\text { of standard } \\
\text { (Diclofenac } \\
\text { sodium) }\end{array}$ \\
\hline & \% Inhibition \\
\hline 1 & 100 & 57.37 & 35.25 \\
\hline 2 & 200 & 69.23 & 51.28 \\
\hline 3 & 300 & 77.88 & 63.14 \\
\hline 4 & 400 & 87.5 & 67.3 \\
\hline 5 & 500 & 91.66 & 70.51 \\
\hline
\end{tabular}

vitro anti-inflammatory and antioxidant activity of chloroform extract of Combretum punctatum var. squamosum even though lesser as compared to standard drugs. But it should be kept in mind that the crude chloroform extract is a mixture of several compounds while standard drugs are pure compounds; and if the compound responsible for such activities can be isolated from the crude extract, there is a possibility that the activities may be even better than the standard drugs. Consequently, to conclude flavonoids and related phenolics present in studied plant materials may possibly be responsible for the important anti-inflammatory and antioxidant activities. However, further investigations are required for identifying the unknown bioactive compounds and to establish their pharmacological 
properties involved in the activities.

\section{Acknowledgement}

The authors gratefully acknowledge the financial grant from Department of Biotechnology, Ministry of Science and Technology, Government of India, through Institutional Level Biotech Hub (IBThub), RIPANS, facilities provided by Director, RIPANS and Department of Pharmaceutical Sciences, Dibrugarh University.

\section{Conflict of interest}

None declared.

\section{References}

1. World Health Organization (2002). Traditional Medicine Strategy 2002-2005. World Health Organisation Publications, Geneva, pp. 1-16.

2. Sandoval, M., Okuhama, N.N., Zhang, X.J., Condezo, L.A., Lao, J. \& Angeles, F.M. (2002). Anti -inflammation and antioxidant activities of cat's claw (Uncaria tomentos and Uncaria guianensis) are independent of their alkaloid content. Phytomedicine, 9, 325-37.

3. Kelly, K. (2009). History of Medicine, Facts on File. New York, pp. 29-50.

4. Rozika, R. (2006). Ramhmul Damdawite, In: Medicinal Plants (Medicinal Plants Board, Mizoram), $2^{\text {nd }}$ Edition.

5. Bhardwaj, S.\& Gakhar, S.K. (2005). Ethnomedicinal plants used by the tribals of Mizoram to cure cuts and wounds. Indian Journal of Traditional Knowledge, 4,75-80.

6. Blois, M.S. (1958). Antioxidant determinations by the use of stable free radical. Nature, 181, 11991200. https://doi.org/10.1038/1811199a0

7. Oyaizu, M. (1986). Studies on products of browning reaction: Antioxidative activity of products of browning reaction. The Japanese Journal of Nutrition and Dietetics, 40, 307-15. https:// doi.org/10.5264/eiyogakuzashi.44.307

8. Mc Donald, S., Prenzler, P.D., Autolovich, M. \& Robards, K. (2001). Phenolic content and antioxidant activity of olive oil extracts. Food Chemistry, 73, 73-84. http://dx.doi.org/10.1016/ S0308-8146(00)00288-0

9. Chang, C., Ming-Hua, Y., Hwei-Mei, W. \& Chuan Chen, W.J. (2002). Determination of total flavonoid content in propolis by two complementary colorimetric methods. Journal of Foodand Drug
Analysis, 10, 178-82.

10. Ohkawa, H., Ohishi, N.\&Yagi, K. (1979). Assay for lipid peroxides in animal tissues by thiobarbituric acid reaction. Analytical Biochemistry, 95, 351-358. https://doi.org/10.1016/0003-2697(79)90738-3

11. Ruberto, G., Baratta, M.T., Deans, S.G.\& Dorman, H.J.D. (2000). Antioxidant and Antimicrobial Activity of Foeniculumoulgare and Crithmum maritimum Essential Oils. Planta Medica, 66, 687693. https://doi.org/10.1055/s-2000-9773

12. Mizushima, Y. \& Kobayashi, M. (1968) Interaction of anti-inflammatory drugs with serum proteins, especially with some biologically active proteins. Journal of Pharmacy and Pharmacology, 20, 169-173. https://doi.org/10.1111/j.2042-7158.1968.tb09718.x

13. Sakat, S., Juvekar, A.R. \& Gambhire, M.N. (2010). In vitro antioxidant and anti-inflammatory activity of methanol extract of Oxalis corniculata Linn. International Journal of Pharmacy and Pharmaceutical Sciences, 2, 146-155.

14. Azeem, A.K., Dilip, C., Prasanth, S.S., Junise, V. \& Shahima, H. (2010). Anti-inflammatory activity of the glandular extracts of Thunnusa lalunga. Asian Pacific Journal ofTropical Medicine,3, 412-420.

15. Bhuiyan, M.A.R., Hoque, M.Z. \& Hossain, S.J. (2009). Free Radical Scavenging Activities of Zizyphus mauritiana. World Journal of Agricultural Sciences, 5, 318-322.

16. Biswas, M., Haldar, P.K. \& Ghosh, A.K. (2017). Antioxidant and free-radical-scavenging effects of fruits of Dregea volubilis. Journal of Natural Science, Biology and Medicine,1, 29-34. http:// dx.doi.org/10.4103/0976-9668.71670

17. Brand-Williams, W., Cuvelier, M.E. \& Berset, C.L.W.T. (1995). Use of a free radical method to evaluate antioxidant activity. LWT-Food Science and Technology, 28, 25-30. http://dx.doi.org/10.1016/ S0023-6438(95)80008-5

18. Soni, A. \& Sosa, S. (2013). Phytochemical analysis and free radical scavenging potential of herbal and medicinal plant extracts. Journal of Pharmacognosy and Phytochemistry, 2, 22-29.

19. Ranjan, S., Rajesh, M. \& Gopi, K.S. (2013). In vitro anti-inflammatory and antioxidant activity of leaf extracts of Datura metal. Asian Journal of Pharmaceutical and ClinicalResearch, 6, 146-149.

20. Coppen, P. P. (1983). The use of antioxidants. In: (J. C. Allen, R. J. Hamilton, eds.) Rancidity in Foods. Applied Science Publishers, New York, USA, p. 67.

21. Onyema, O.O., Farombi, E.O., Emerole, G.O., Ukoha, A.I. \& Onyeze, G.O. (2006). Effect of 
vitamin $\mathrm{E}$ on monosodium glutamate induced hepatotoxicity and oxidative stress in rats. Indian Journal of Biochemistry and Biophysics, 43, 20-24.

22. Mizushima, Y. \& Kobayashi, M. (1968). Interaction of anti-inflammatory drugs with serum proteins, especially with same biologically active proteins. Journal of Pharmacy and Pharmacology, 20, 169-173. https://doi.org/10.1111/j.2042-7158.1968.tb09718.x

23. Fayyaz, A., Rafeeq, A. K. \& Shahid, R. (1992). Study of analgesic and anti-inflammatory activity from plant extracts of Lactuca scariola and Artemisia absinthium. Journal of Islamic and Academic Sciences, 5, 111-114.

24. Weissmann, G., Spilberg, I. \& Krakauer, K. (1969). Arthritis induced in rabbits by lysates of granulocyte lysosomes. Arthristis \& Rheumatism. 12, 103-116. https://doi.org/10.1002/art.1780120207
25. Mounnissamy, V.M., Kavimani, S., Balu, V. \& Drlin, Q.S. (2008). Evaluation of anti-inflammatory and membrane stabilizing properties of ethanol extract of Canjerar heedii. Iranian Journal of Pharmacology and Therapeutics, 6, 235-237.

26. Hess, S.M. \& Milonig, R.M. (1972). Assay for antiinflammatory drugs. In: Inflammation: Mechanisms and Control (Lepow IH, and Ward PA, eds.), Academic Press, New York, pp. 1-12.

27. Oyedapo, O.O., Akinpelu, B.A., Akinwunmi, K.F., Adeyinka, M.O. \& Sipeolu, F.O. (2010). Red blood cell membrane stabilizing potentials of extracts of Lantana camara and its fractions. International Journal of Plant Physiology and Biochemistry, 2, 4651. 